\title{
$369^{\text {ste }}$ BESTUURSVERGADERING
}

VAN 21 MAART 1896.

Aanwezig: de HH. der Kinderen (Voorzitter), Pijnacker Hordijk (Ondervoorzitter), Spanjaard, Poensen, Groeneveldt, J. J. M. de Groot, Martin, J. H. de Groot (Penningmeester), en Kielstra (Secretaris).

Afwezig, met kennisgeving, de HH. van der Lith en van Limburg Stirum.

De Onder-voorzitter opent de Vergadering en verwelkomt de nieuw opgetreden bestuursleden.

De notulen der bestuursvergadering van 15 Februari jl. worden gelezen en goedgekeurd.

De notulen der Algemeene Vergadering van 22 F'ebruari jl. worden gelezen en, in afwachting van de goedkeuring door de volgende Algemeene Vergadering, voorloopig vastgesteld.

Tot voorzitter, ondervoorzitter, penningmeester en secretaris worden resp. gekozen de HH. der Kinderen, Pijnacker Hordijk, J. H. de Groot en Kielstra, die zich bereid verklaren genoemde functiën te vervullen. De heer Pijnacker Hordijk draagt, met een woord van waardeering, het voorzitterschap aan den heer der Kinderen over.

De heer der Kinderen aanvaardt het presidium.

Ingekomen zijn mededeelingen van de HH. M. J. van Baarda, H. W. A. van den Wall Bake, R. W. J. C. van den Wall Bake, Jhr. W. H. Teding van Berkhout, W. Broese van Groenou, Prof. dr. C. H. Th. Bussemaker, R. van Eck, O. C. Eschauzier, G. J. van Heek, P. J. F. van Heutsz, $\mathbf{m}^{\mathrm{r}}$. G. van der Jagt, B. C. de

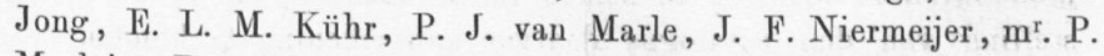
Maclaine Pont, A. J. Prager, A. Prell, E. K. G. Rose, J. W. H. van Soest, W. Stork, D. Tollenaar, Jlr. J. A. W. L. Cornets de Groot van Kraaijenburg en $\mathrm{m}^{\mathrm{r}}$. J. H. Fransen van de Putte dat zij bereid zijn de benoeming tot lid van het Instituut te aanvaarden.

1896. 
Op voorstel van den Secretaris worden met algemeene steminen benoemd:

tot buitenlandsch lid, de heer Auguste Barth te Parijs;

tot gewone leden, de heeren J. C. van der Belt en $\mathrm{m}^{\mathrm{r}}$. D. Mounier, beide te 's Gravenhage.

Van $\mathrm{D}^{\mathrm{r}}$. Groneman en $\mathrm{m}^{\mathrm{r}}$. A. Teixeira de Mattos is bericht ontvangen van veranderd adres; laatstgenoemde, benevens de heer E. F. Kruyf, wenschen met het einde des jaars hun lidmaatschap te doen eindigen.

Notificatie.

Van den Schrijver, Generaal P. M. Netscher, is ontvangen een exemplaar van zijn geschrift over de grensscheiding van BritschGuiana en Venezuela.

Aan Generaal Netscher is daarvoor bereids dank betuigd.

Door den heer Aristide Marre te Parijs is de vraag gesteld, of het Instituut genegen zoude zijn eene uitgaaf te bezorgen van de Hikajat toean poetri Djohar Manikam (naar een bijzonder fraai te Parijs aanwezig handschrift), getranscribeerd in latijnsche letters en voorzien van eene Fransche vertaling.

$\mathrm{Na}$ uitvoerige gedachtenwisseling wordt besloten, te antwoorden dat deze uitgaaf minder kan worden geacht op den weg te liggen van het Instituut.

Van het lid J. K. W. Quarles van Ufford is een schrijven ontvangen dd. 22 Februari jl. waarin hij alsnog ten behoeve der bibliotheek aanbiedt een exemplaar der maileditie van het Bataviaasch Handelsblad over 1895, en zijn leedwezen betuigt dat in de notulen van 15 Juni a. p. niet is vermeld dat de destijds door hem gezonden deelen ingebonden waren, aangezien belangstellenden er eerder toe komen, boekdeelen te raadplegen dan bundels dagbladen.

Wordt besloten, alsnog van den ingebonden staat der reeks mailcouranten melding te maken in de notulen, en bij de samenstelling van den catalogus daarvan aanteekening te houden.

Het bestuurslid Niemann geeft in overweging, een voorstel te doen tot ruiling der Instituutswerken met die van het Kön. Ethnogr. Museum te Dresden.

Dienovereenkomstig wordt besloten. 